\title{
Chapter 7 \\ Mediation and Conciliation of Collective Labor Conflicts in Germany
}

\author{
Klaus Harnack
}

\subsection{Introduction}

On December 23, 2016, the union of the German train drivers (GDL) declared, after six rounds of negotiations, the failure of the collective bargaining process and called for an arbitration. Subsequently both sides appointed one of two impartial chairpersons. The union GDL appointed the prime minister of Thüringen, Bodo Ramelow and the employers' association (Agv-MoVe), appointed the former prime minister of Brandenburg, Matthias Platzeck. Based on the basic collective agreement, which was signed by both sides in 2015 , after their last negotiations, the arbitration committee needed to find an agreement within three weeks after the beginning, with the option of extra time, if both parties agree. The result of this procedure was either a wage settlement and a joined agreement, or a strike. During the arbitration, there was an obligation for peace. Formal beginning of the arbitration was the 11th January 2017 and ended on March 9, 2017, after several extensions with a binding agreement between GDL and Agv-MoVe in Berlin. The arbitration was thus successfully completed and the disputes settled. Both impartial chairpersons were neither mediators nor arbitrators in a strict sense (neither certified nor especially trained), but public people with a high public reputation that guaranteed their neutral position and their potential to reach integrative negotiation results. Although this example represents a third party supported negotiation in the field of large-scale labor conflict, this sample case remains a rare exception in Germany.

The following chapter will depict the current situation in Germany with regard to third party intervention in labor conflict. Referring to the introductory sample case, it is not obligatory in Germany to conduct a mediation or seek help of a third neutral party, if both sides cannot find a common solution and a threat of strike rises. The reason why it is not mandatory to have a third-party intervention in such situations,

\footnotetext{
K. Harnack $(\bowtie)$

Department of Psychology (WOP), University of Münster, Fliednerstraße 21, 48149 Münster, Germany

e-mail: klaus.harnack@uni-muenster.de
}

(C) The Author(s) 2019 
is due to the culture of collective conflict in Germany, which is shaped by the principle of collective bargaining autonomy. This autonomy is deeply anchored in the constitution and is expressed via two different mechanisms. First the Convention Collectives [Tarifverträge] - a contract between the social partners (usually unions and employers) that functions as a regulator on the higher level and second the German Works Constitution Act [Betriebsverfassungsgesetzes] that functions as a regulator within companies (the main procedures are based on article $\$ 76$ Works Constitution Act ('BetrVG', 1972). Both mechanisms considerably shaped the industrial relations tradition in Germany after World War 2 and both are still the basic fundament of all collective labor actions, culture and habits.

Unions have a strong position in Germany, compared to many other countries. This is both based in labor laws, guaranteeing the position of unions and works councils, and due to the long tradition of the autonomy of partners in collective bargaining processes (Whittal, 2015). Due to this, both employees as well as employers feel empowered in negotiations, and are not used to have a third party involved in their disputes and negotiations, hence any third party, even a neutral mediator, is not very common. Some key figures from the employee side in the industry and service sector have a privileged position in their threat potential; for instance air traffic controllers, hence they do not see the necessity to seek help of a mediator.

Nevertheless, third party interventions or mediations are sometimes utilised to solve collective conflicts. The main prerequisite in order to start a third party supported negotiation process is that both parties wish to do so, which is rarely the case and there is no regulation on this issue. In principle, it could take place at any stage of the conflict process, but in practice, it is only applied, if bilateral negotiations fail and if it was part of prior agreements or consultation. In cases of third party intervention, the question who typically acts as mediator has no clear-cut answer and differs between conflicts in the public and private sector. In the private sector, these third parties (or mediators) remain largely unknown and work in the background. For instance, the German Lufthansa and the union of the pilots (Vereinigung Cockpit) have been seeking support of a mediator in 2014 after their negotiations were deadlocked, but the public was only informed several weeks later and the name of the mediator as well as the applied procedure and style remained unknown. This does not hold true for the public domain. In the past, famous people or former politicians conducted several public third party conflict interventions. For instance, Heiner Geißler (former Federal Minister) acted as an arbitrator in the case of "Stuttgart 21" and Bodo Ramelow (State Premier of Thüringen) together with Matthias Platzeck (former State Premier of Brandenburg) mediated in the case between the Deutsche Bahn and the union of the German train drivers (GDL) in 2015. These persons are not mediators in a strict sense (certified or trained), but people with a high public reputation that guarantees their neutral position and their potential to reach integrative negotiation results. Both parties organize the selection of supporting third parties. Each side has the right to make recommendations without any limitations. During the process, which is not clearly defined as an arbitration or a mediation, the recommended persons take alternating turns in supporting the parties in conflict. 
Table 7.1 Development of mediation procedures and culture in Germany

\begin{tabular}{l|l}
\hline Year & Events and milestones \\
\hline $1960-1990$ & $\begin{array}{l}\text { Beginning of theoretical development of first extrajudicial conciliation } \\
\text { procedures }\end{array}$ \\
\cline { 2 - 3 } & $\begin{array}{l}\text { Broader and public discussions on alternative conflict/“Import hit from America" } \\
\text { Mediation procedures are developed and tested (Besemer, 2001) }\end{array}$ \\
\hline 1992 & $\begin{array}{l}\text { Founding year of the Federal German Association Mediation (Bundesverband } \\
\text { Mediation e.V.) }\end{array}$ \\
\hline 1998 & $\begin{array}{l}\text { Founding year of the German Society for Mediation (Deutsche Gesellschaft für } \\
\text { Mediation: DGM), German Society for Business-Mediation (Deutsche } \\
\text { Gesellschaft für Mediation in der Wirtschaft), Mediation consortium of the } \\
\text { German Lawyer's Society (Arbeitsgemeinschaft Mediation-Deutscher } \\
\text { Anwaltsverein) }\end{array}$ \\
\hline 2009 & $\begin{array}{l}\text { Founding year of the first umbrella organisation for mediation-Deutsches } \\
\text { Forum für Mediation DFfM e.V }\end{array}$ \\
\hline 2016 & Mediation Act \\
\hline 2017 & $\begin{array}{l}\text { Regulation on the education and training of certified mediators } \\
\text { First evaluation of the German Mediation Law by the German Research Institute } \\
\text { for public administration in Speyer. This evaluation did not include mediation or } \\
\text { arbitration for collective labor conflicts }\end{array}$ \\
\hline
\end{tabular}

${ }^{a}$ Deutsche Gesellschaft für Mediation: DGM; German Society for Business-Mediation (Deutsche Gesellschaft für Mediation in der Wirtschaft), Mediation consortium of the German Lawyer's Society (Arbeitsgemeinschaft Mediation—Deutscher Anwaltsverein)

These examples illustrate that mediation or third party support remains an exceptional instance to ease collective conflict in Germany. This holds particular true for escalation prevention. The reason for this sealed off and closed behavior is mainly due to the deeply rooted culture of two exclusive sides as well as the rather short history of mediation as a recognized professional activity in Germany (compare Table 7.1).

\subsection{The Role of Strikes in Germany}

Compared to other European countries, strike is not a very pronounced topic of national debates and unions do not use it extensively (see Fig. 7.1). In order to characterize the German industrial relations tradition, the term "orientated towards consensus" is probably the best way to describe the main tradition (Whittal, 2015). Most strikes are "warning strikes", with just a fraction of the total employees and with a limited duration (mostly just a single day). Concerning the distribution of strikes over the working sectors, there is tendency that the production industry reduced their strike activities and that most strikes were conducted by the service sector. Some of the interviewed experts stated: "People with customer contact are more likely to 
Strike situation in Germany from 2004 to 2017

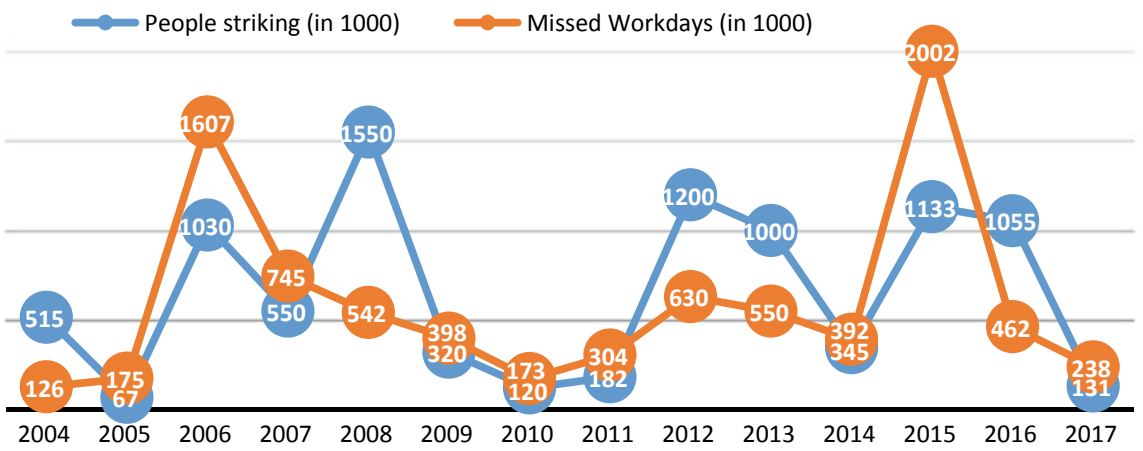

Fig. 7.1 People in strike and strike days in Germany from 2006 to 2015 (WSI-2018)

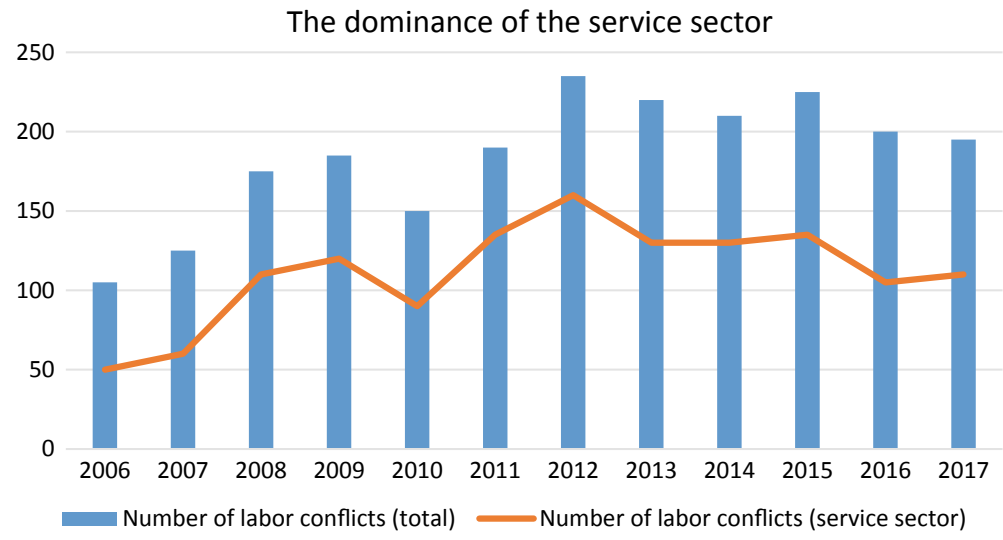

Fig. 7.2 Number of labor conflicts and the proportion of the service sector from 2006 to 2017 (WSI-2018)

seek strike"- the graphic below supports this idea (see Fig. 7.2). Due to the shielded nature of labor conflicts, it is important to notice is, that no systematic records are available on third party interventions in these conflicts.

\subsection{Characteristics of the System}

There are usually only two active sides in labor conflicts (employers' associations and unions). This due to the autonomy in wage bargaining, which is based on the Basic Law of the Federal Republic of Germany [Grundgesetz] Art. 9. Abs. 3: 
The right to form associations to safeguard and improve working and economic conditions shall be guaranteed to every individual and to every occupation or profession. Agreements that restrict or seek to impair this right shall be null and void; measures directed to this end shall be unlawful. Measures taken pursuant to Article 12a, to paragraphs (2) and (3) of Article 35, to paragraph (4) of Article 87a, or to Article 91 may not be directed against industrial disputes engaged in by associations within the meaning of the first sentence of this paragraph in order to safeguard and improve working and economic conditions.

Article 9 explicitly underlines and explains the bilateral tradition concerning the handling of conflicts - free of all interventions by governmental and state organizations, especially for the labor agreements, wages, and strikes. It is all about the tradition of free labor agreements.

Although being free of all interventions, this does not mean that support of a third party is prohibited. Depending on the conflict and parties involved, the mechanism how mediators might get involved differs. In collective labor conflicts (tariff negotiation, including issues like payment, work security and work conditions), a third party might be invited into the conflict resolution procedures, if one of the parties calls the negotiation failed (see the sample case). If the parties chose mediation as a potential way to solve their conflict, a dead-end situation in their negotiation is most often the case and the contestants have a strong interest in their future relationship. In addition, a high case complexity is one major motivator to opt for a mediation, as well as conflicts that are concerned with values rather than jurisdictional matters. Figure 7.3 illustrates the reasons for choosing a mediation or similar ADR procedures (although the survey is based on in-house conflicts, according to some interviewed experts, the underlying reasoning can be applied to collective conflicts as well). The recommendation of external persons and the initiation of the proceedings of the opposing party have increased particularly in the last ten years (PwC/EUV, 2016).

Independent of the area of application, mediation remains a voluntary process in Germany. According to the German Mediation Law (MediationsG, 2012), mediation cannot be ordered by law nor by the courts at any point before or during a court proceeding. Judges may recommend mediation, but both parties must agree in order to start a mediation process. Furthermore, there are voluntary self-commitments, like the RTMKM (Förderverein Round Table Mediation \& Konfliktmanagement der Deutschen Wirtschaft e.V. 2016) in which the signing companies commit themselves in the event of a conflict with another signatory, to follow preferably alternative dispute resolution proceedings. Similar procedures are sometimes applied in collective conflicts. As described in the introductory example, the parties might sign a basic collective agreement, which allows and plans arbitration committees in case of negotiation deadlocks.

If parties agree to use the support of a third party, several databases are available in order to find a suitable third neutral party. Besides privately organised internet portals, mediation organizations provide registers and indices as an additional value to their membership services. There are several directories, categorized by region and expertise (e.g. economy, patent, families, etc.). The contact information of suitable qualified mediators can be either obtained through the indices of major mediator associations, such as the DGM, the BMWA, or the BM sometimes at the Chambers 
Reasons for ADR-procedures in B2B and individual labor conflicts

$1=$ never, 2 = rarely, 3 = at times, 4 = frequent, $5=$ always

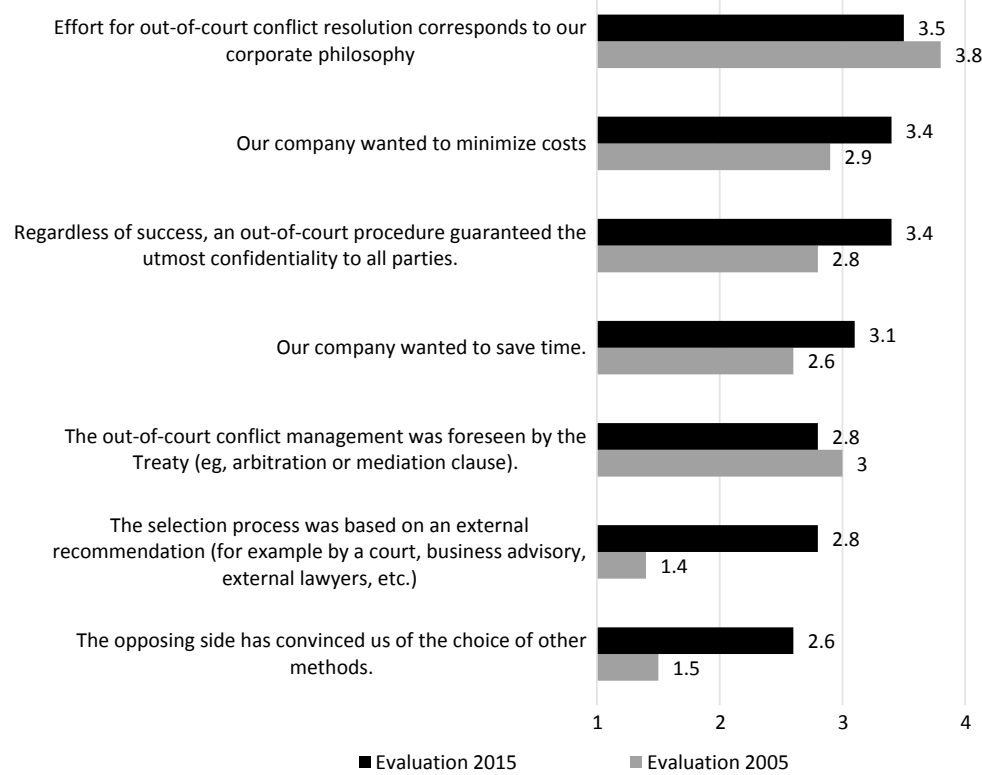

Fig. 7.3 Survey based on in-house mediations (150 companies with at least 50 employees and 32 members of RTMKM) (PwC-2016)

of Industry and Commerce, or simply by recommendations (Koschany-Rohbeck, 2015). In collective conflicts, the parties usually have a set of trusted individuals and these people become appointed, when one of the parties call the negotiation as failed. Due to the lack of research in the field of collective labor conflicts and the missing transparency of these processes, there is no clear evidence what kind of procedures are applied when third parties get involved. Also, there is a lack of data on the amount of collective conflicts in which third parties were invited, whom these were and what results were obtained. The interviews with the experts revealed that the pointed people are almost exclusively part of their personal and professional network.

\subsection{Evaluation of Stakeholders on the System}

Even though third-party intervention is not commonly used in collective conflicts, the basic approach - the spirit of mediation-is present behind the scenes. Several experts pointed out that the legal supporters and advisors on both sides are usually well trained in integrative negotiation. Hence, the tools of mediation are simply 
used by these advisors instead of a "real mediator"- a separate and independent person. As part of the prior composition of the negotiation teams, some have the explicit role as an integrative element. These persons search for common interests and have a strict focus on the interests and resources of both sides. Even if both sides present themselves in public as very contradicting with a distributive mind-set, on the negotiation table there are integrative elements present as well. One expert said, "They like to play the game-especially the unions - in order to justify their position and legitimize their existence".

Concerning the legal structure, almost all experts called for improvements. For collective conflicts, several experts pointed out that there are no efforts to improve and strengthen preventive actions, because it could contradict the above-mentioned "game". Most comments were directed towards the field beyond labor conflicts. Here the use of third parties is still not yet exhausted. This is mostly due to the predominance of lawyers who seem to be not interested in a process without them and the problem was not tackled with the German mediation law nor in other pieces of legislature. When it comes to works councils, third parties could offer assistance preventing conflict escalation. There is no documented research on this third-party role, however.

Another issue that was addressed by the experts is the financial support for collective problems on the local level, like conflicts between civic association and the local governments. Here the parties cannot financially afford the support of a mediator, although it could prevent costly legal proceedings in the end.

\subsection{How Many Mediators Are There in Germany?}

Since a standard definition of the mediator's job-profile is difficult, a precise answer of the question is not possible, bearing in mind that until August 2016 the training of a certified mediator was not regulated by law. Nevertheless, one parameter might be suitable to establish a rough estimation: It is the number of memberships in German mediation organizations. Table 7.2 depicts all major German mediation organizations together, with an estimated number of memberships. In total, between 7000 and 9000 mediators in Germany are organized in mediation associations. The interviewed experts estimated the number of mediators that could function in collective conflicts by approx. 100 .

\subsection{Who Act as a Mediator in Germany?}

The German Mediation Law states: A mediator is an independent and neutral person who guides the parties through the mediation without any authority to decide. The general job title is not protected, but the title "certified mediator" is protected by paragraph $\S 5$ and $\S 6$ of the German Mediation Law (MediationsG, 2012). Hence, 
Table 7.2 Membership of German mediation organizations (November 2016)

\begin{tabular}{l|l}
\hline Organization & Number of memberships \\
\hline BMEV & More than 2500 members/mediators (BMEV, 2016) \\
\hline BAFM & 800 members/mediators (BAFM, 2016) \\
\hline DGMW & 119 members/mediators (DGMW, 2016) \\
\hline BMWA & 350 members/mediators (BMWA, 2016) \\
\hline DFfM & $\begin{array}{l}\text { Umbrella organization, including 12 organizations with in total more than } 2700 \\
\text { members/mediators }\end{array}$ \\
\hline IM & 350 members/mediators (IM, 2016) \\
\hline DGM & 600 members/mediators \\
\hline
\end{tabular}

${ }^{a}$ Berufsverband Deutscher Diplom-Pädagogen und Diplom-Pädagoginnen BDDP

Deutsche Gesellschaft für Mediation in der Wirtschaft DGMW

Deutsche Gesellschaft für Transaktionsanalyse DGTA

Europäisches Institut für Conflict Management EUCON

Contarini-Institut für Mediation an der FernUniversität in Hagen

Fördergemeinschaft Mediation DACH; Förderverein Mediation im öffentlichen Bereich FMÖB

Integrierte Mediation IM

Steinbeis-Hochschule-Berlin, Akademie für Mediation, Soziales und Recht

Steinbeis-Mediationsforum e. V. StMf (220 mediators)

Verband der Bau- und Immobilienmediatoren e. V

Verein Deutscher Patentanwälte zur Förderung der Mediation

anyone can act as a mediator and this is especially true for collective conflicts. The access requirements for the training as a certified mediator differs depending on the training institutes: Some institutes train only academics with a legal or psychological, pedagogical or social basic profession background, others are open to all occupations, but usually all require a completed professional education.

The training regulations, covered by the German Mediation Law, comprise $120 \mathrm{~h}$ of attendance in which different fields of knowledge and skills are trained. Federal associations offer training courses that require at least $200 \mathrm{~h}$. Depending on the institution, it can be between 50 and $300 \mathrm{~h}$. The ordinance on the education and training of certified mediators, issued by the Federal Ministry of Justice and Consumer Protection, also prescribes the mediators to develop steadily. Within four years (after issuing the certificate), $40 \mathrm{~h}$ of further training are required (Bundesministerium der Justiz für Verbraucherschutz, 2017). Even though mediation is steadily growing and developing as a professional activity in many societal fields, we notice that collective labor conflicts are hardly connected to this development and does not (yet) use the potential of qualified mediators. 


\subsection{Evaluation by Stakeholders of the Facilitators/Mediators and Third Party Procedures}

The underlying structure and procedure in mediation in Germany clearly is different for collective labor conflicts, compared to other contexts. If a third party joins the collective labor negotiations, they try to incorporate and integrate the stance of both sides into possible solutions. The general approach of mediation that the clients need to find their own solution is not applied.

A formal agreement in the case of a mediation success is not required by law ( $\$ 2$. MediationsG), but it is part of the mediation culture. Many companies that have used an in-house mediation are issued a joint statement, of course only in the case of non-judicial cases. In such a case, which usually occurs between two companies, a legally binding contract is established (Diez, 2005). For collective conflicts, there are only two possible outcomes, a collective agreement, or a strike and no common document.

\subsection{Is There Any Documentation on Satisfaction with the Mediation?}

The Roland law report [Roland Rechtsreport] documents that roughly $50 \%$ of the general population believes that mediation is a useful tool and that about $60 \%$ of people that know about mediation, states that mediation is a potential tool to solve conflict (Institut für Demoskopie Allensbach, 2014). The "Kieler Studie" (Kaiser \& Gabler, 2014) investigated the topic directly: Namely direct after the mediation procedure and one year later (See Fig. 7.4 for results).

\subsection{Is There Change in the Use of Mediation?}

In Germany, an increasing trend towards mediation is recognizable. A study conducted by PricewaterhouseCoopers AG and the European University Viadrina Frankfurt in 2016 compared results from a survey conducted in 2005 (182 companies) and one from 2015. Although both surveys differed slightly, a significant increase in the use of mediation procedures was observed. Figure 5 shows how the process of mediation and conciliation has increased over the past ten years (PwC/EUV, 2016). 


\subsection{The Use of Third Party Intervention in Work Councils}

The Work Council Constitution Act [Betriebsverfassungsgesetz] rules the relationship between the employer and its employees in Germany. In addition, the act determines the basic rights of employees concerning staff-related as well as economic issues. Depending on the size of the company, a certain number of members can be send to the council, starting with one member for five permanently employed employees up to 35 members for companies between 7001 and 9000 employees with 2 additional members for each 3000 employees. It is important to notice that it is not mandatory to establish work councils. However, employees have the right to do so, and it is best practice. Generally, relations in the works council between employer and employee representatives are good, and trust in this relation is often high (Whittal, 2015), resulting in a valued cooperation at company level.

The expert interviews revealed that an increasing number of work council members are currently trained in mediation and other ADR-techniques in order to professionalize and smoothen the procedure within work councils as well as with their interacting partners. As the experts pointed out, this training is not systematic nor mandatory for either side. Similar to prior described labor related contexts, an implicit use of mediation is developing. In addition, mediators as well as other professionals are occasionally invited to structure and support the work of the work councils in order to foster collective problem solving, before these cases are taken to the labor court or rather to the "Güterichter". The employers usually initiate these procedures, because they fear that the strong propositions by the "Güterichter" might not be in favor of the company.

A unique feature of the German jurisdiction system are the so-called "Güterichter". The responsible judge can, in order to favour amicable settlements of the disputes, refer the parties for a negotiation or mediation to another judge

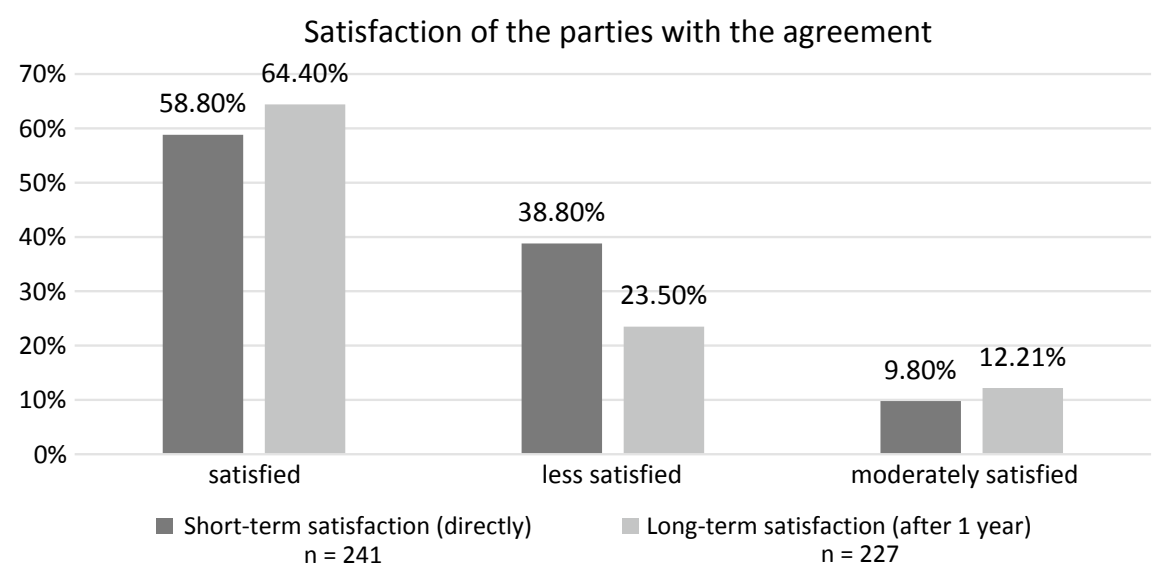

Fig. 7.4 Satisfaction of the parties with the agreement (Kaiser-2014) 


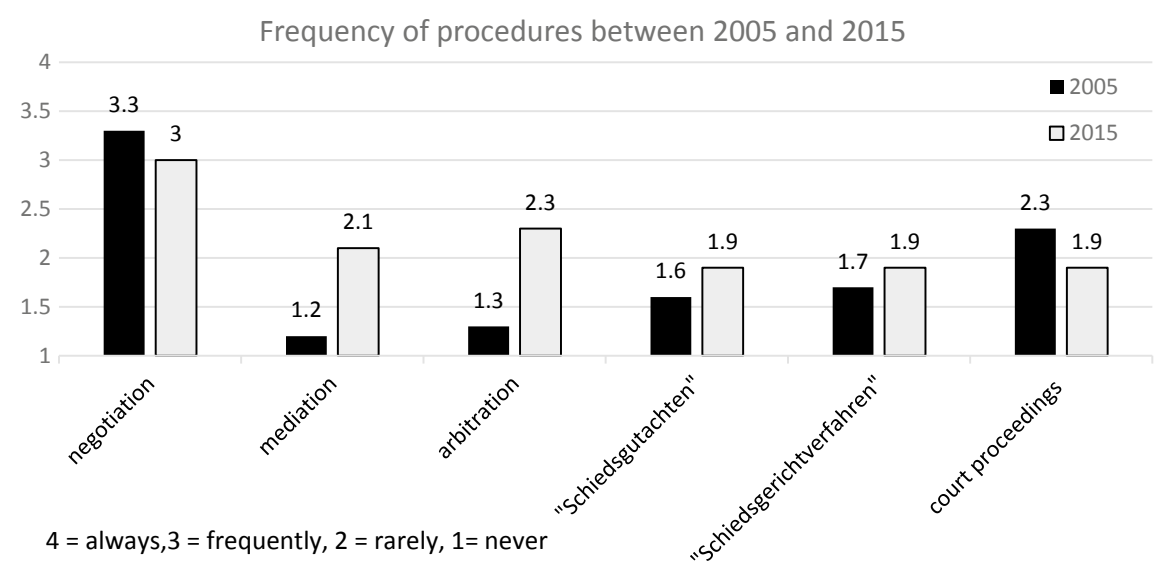

Fig. 7.5 Alternative conflict resolution procedure in 2005 and in 2015 (PwC-2016)

appointed for this purpose and not authorized to make decisions (\$278 Abs. $1 \mathrm{ZPO})$. The appointed judge is not bound to a certain technique to tackle the problem, but has instead, the free procedural choice and can utilize the complete range of ADR-techniques. Analogue to the procedures in the civil justice system is the procedural approach, concerning labor conflicts. If a labor conflict escalates and the case is brought to the court, the labor courts may appoint "Güterichter" in a similar manner (compare §278(5) ZPO, §54(6) ArbGG). It is important to notice that these judges do not have to be a certified mediator.

The court may also propose to the parties a mediation or other out-of-court settlement procedure $(\$ 54 \mathrm{a}(1)$ ArbGG). If the parties decide to conduct a mediation or other out-of-court settlement procedure, the court orders the proceedings to be suspended. Otherwise, the court resumed the proceedings after three months, unless the parties agree that mediation or out-of-court settlement of conflicts is still ongoing ( $\$ 278 \mathrm{a} \mathrm{ZPO}, \S 54 \mathrm{a}$ ArbGG). Insofar as mediation is required to resolve conflicts in order to ensure proper and trouble-free works council work, the employer has to bear the costs ( $\$ 40$ Abs.1 BetrVG). Nevertheless, there are no specialized national institutions or databases that support this process. Mediators or supporting third parties can be freely chosen by the parties and are usually part of either sides' professional network. 


\subsection{Is There Indication of Trust or Distrust in the System and in the Quality of Mediations (Process) and Mediators?}

In 2013 the Academicon ADR-Report was released, containing survey results from 589 middle to large German companies about alternative conflict resolution procedures (Academicon, 2013). It revealed that the certification of a mediator is not important for companies, but rather the perception of competence and the recommendation of others function as signal of trust. In addition, the authors state that German companies are increasingly recognizing out-of-court conflict resolution procedures as an effective method in order to save of litigation costs, to limitation of legal risks as well as a possibility for a speedy conflict resolution.

\subsection{Is There at Systems Level an Evaluation of the Costs and Benefits of the Mediation System?}

To the authors as well as the expert's knowledge there is no direct evaluation of the costs and benefits of the mediation system in Germany. There is a debate about the cost of conflict, but not about the positive aspects of mediation per se. There is no link between mediation and reduced strike activity. Although the trend towards alternative dispute resolution methods is increasing in Germany, this does not reflect less competition. There is hardly debate about introducing more "professional" mediators in the arena of collective labor conflicts.

Generally, the prior mentioned study in Kiel recommended better education, training and psychological counselling of mediators and lawyers. Heiko Maas, Federal Minister of Justice and Consumer Protection, said after the release of this report: ,, The study shows that mediation is applied in different settings throughout Germany, but it also shows that the potential still far from being fully realized." (BMJV-19.07.2017). This could be extended to collective labor conflicts certainly.

\subsection{Conclusion and Suggested Improvements}

In conclusion, there are several suggestions made by the experts to foster and support mediation for workplace conflicts as well as for collective conflicts. One suggestion by several experts regards the issue of strict voluntariness. In their opinion, the issue of voluntariness seems overrated and is more an obstacle, than a support for the process, and with less voluntariness more people would make use of mediation (Harnack, 2016, 2017). This accounts for all kinds of mediations.

Concerning collective conflicts, same experts stated, "Germany is trapped in its culture of bilateral negotiation" or "They want to play the game - Both sides need 
to establish and strengthen their position through that game". Another emphasized the importance of more information on third party interventions and mediation in collective conflicts: "The benefits of mediation or alternative procedures are usually only seen if participants experienced at least once themselves and experienced the advantages of mediation. All experts agreed that a wider debate would foster mediation, that mediation has the potential to strengthen the social peace, but they do not recognize that such a debate is currently going on.

\section{References}

ArbGG. (2018). Retrieved 05 December 2018, from http://www.gesetze-im-internet.de/arbgg/ index.html.

Academicon (Ed.). (2013). ADR-Report 2013 zur außergerichtlichen Streitbeilegung in Unternehmen. Norderstedt. Retrieved from http://www.academicon.net/adr-report-2013-zuraussergerichtlichen-streitbeilegung-deutschen-unternehmen/.

Besemer, C. (2001). Mediation: Vermittlung in Konflikten (1.). Königsfeld: Stiftung Gewaltfreies Leben.

Betr, V. G. (1972). Retrieved 30 January 2017, from http://www.gesetze-im-internet.de/betrvg/ index.html.

Bundesministerium der Justiz für Verbraucherschutz. (2017). Verordnung über die Aus-und Fortbildung von zertifizierten Mediatoren (Zertifizierte-Mediatoren-AusbildungsverordnungZMediatAusbV) (2017).

Diez, H. (2005). Werkstattbuch Mediation (1st ed.). Köln: Centrale für Mediation: Schmidt, Otto.

Förderverein Round Table Mediation \& Konfliktmanagement der Deutschen Wirtschaft e.V. (2016). Round Table Mediation und Konfliktmanagement der deutschen Wirtschaft. Retrieved 3 October 2016, from http://www.rtmkm.de/.

Harnack, K. (2016). A psychological toolbox for mediators: From theory and research to best practices. In K. Bollen, M. Euwema, \& L. Munduate (Eds.), Advancing workplace mediation through integration of theory and practice (pp. 55-66). Springer International Publishing. https:// doi.org/10.1007/978-3-319-42842-0_4.

Harnack, K. (2017). Der Mediator als Katalysator. In Kracht, A. Niedostadek, \& Sendburg (Eds.), Praxishandbuch Professionelle Mediation. Berlin: SpringerVS.

Institut für Demoskopie Allensbach. (2014). Roland Rechtsreport 2014-Einstellung der Bevölkerung zum deutschen Rechtssystem, zur Chancengleichheit und zur Mediation. Köln.

Kaiser, P., \& Gabler, A. M. (2014). Prozessqualität und Langzeiteffekte in der Mediation-Ergebnisse aus der Kieler Longitudinalstudie. ZKM-Zeitschrift Für Konfliktmanagement, 180-184.

Koschany- Rohbeck, M. (2015). Praxishandbuch Wirtschaftsmediation: Grundlagen und Methoden zur Lösung innerbetrieblicher und zwischenbetrieblicher Konflikte. Wiesbaden: SpringerGabler.

MediationsG (2012). Retrieved from https://www.gesetze-im-internet.de/mediationsg/.

Montada, L., \& Kals, E. (2001). Mediation (1st ed.). Weinheim: BeltzPVU.

Orca-Institut. (2012). Wann ist Mediation sinnvoll? Retrieved 27 October 2016, from http://www. orca-institut.de/mediation/wann.htm.

PwC/EUV (Ed.). (2016). Konfliktmanagement in der deutschen Wirtschaft - Entwicklung eines Jahrzehnts. Frankfurt am Main.

Whittal, M. (2015). Management perceptions of social dialogue at the company level in Germany. In Euwema et al (eds). Promoting social dialogue in European Organizations. pp. 79-92.

WSI-Wirtschafts-und Sozialwissenschaftliches Institut. (2016). WSI- Arbeitskampfbilanz 2015. Hans-Böckler-Stiftung.

ZPO. (2018). Retrieved 05 December 2018, from http://www.gesetze-im-internet.de/zpo/index. html. 
Open Access This chapter is licensed under the terms of the Creative Commons Attribution 4.0 International License (http://creativecommons.org/licenses/by/4.0/), which permits use, sharing, adaptation, distribution and reproduction in any medium or format, as long as you give appropriate credit to the original author(s) and the source, provide a link to the Creative Commons license and indicate if changes were made.

The images or other third party material in this chapter are included in the chapter's Creative Commons license, unless indicated otherwise in a credit line to the material. If material is not included in the chapter's Creative Commons license and your intended use is not permitted by statutory regulation or exceeds the permitted use, you will need to obtain permission directly from the copyright holder.

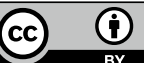

